\title{
Organic, mineral and nutrient substances in the atmospheric precipitation of Barnaul
}

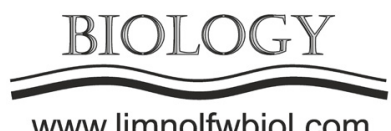

\author{
Lysenko M.S. *, Noskova T.V., Podchufarova D.P., Papina T.S.
}

Institute for Water and Environmental Problems, Siberian Branch of the Russian Academy of Sciences, Molodezhnaya Str., 1, Barnaul, 656038, Russia

\begin{abstract}
The objective of this work was to study the annual dynamics and seasonal changes in the concentration of organic (determined by the content of organic carbon) and mineral $\left(\mathrm{Cl}^{-}, \mathrm{SO}_{4}^{2-} \mathrm{Na}^{+}\right.$, $\left.\mathrm{K}^{+}, \mathrm{Mg}^{2+}, \mathrm{Ca}^{2+}\right)$ substances and nutrients $\left(\mathrm{NO}_{3}^{-}, \mathrm{NH}_{4}^{+}, \mathrm{NO}_{2}^{-}, \mathrm{PO}_{4}^{3-}\right)$ in atmospheric precipitation of Barnaul. This paper presents the results of a study of precipitation (rain and snow) for the period from October 2013 to March 2020. The seasonal and annual dynamics of changes in the concentration of the studied components were considered. It was found that seasonal variability of $\mathrm{NO}_{3}^{-}, \mathrm{Cl}^{-}, \mathrm{SO}_{4}^{2-,} \mathrm{Na}^{+}$, $\mathrm{K}^{+}, \mathrm{PO}_{4}^{3-}$ concentrations was the highest in the cold period. The annual increase of the total amount of the studied ions, as well as organic carbon, was proportional to the number of pollutants entering the atmosphere of Barnaul from industrial enterprises and automobile transport.
\end{abstract}

Keywords: organic and mineral substances, nutrients, atmospheric precipitation, seasonal dynamics, pollution

\section{Introduction}

Atmospheric air is a vital component of the environment; therefore its monitoring is an urgent problem in the modern world. In large populated and industrial centers, atmospheric moisture adsorbing all urban emissions forms precipitation containing pollution of both natural and anthropogenic origin (Svistov and Polishchuk, 2014). Therefore, the chemical composition of atmospheric precipitation is an indirect indicator of the level of ambient air pollution, which allows us to simultaneously receive information about both the state of the atmosphere and the possible consequences of its pollution for the environment (aquatic ecosystems, soil, vegetation, etc.) (Golubnichy et al., 2014).

The study of the emission, transformation and circulation of organic (determined by the content of $\mathrm{C}_{\text {org }}$ ) and mineral substances and nutrients is a crucial task of environmental monitoring in a changing climate and increased pollution associated with anthropogenic activities.

The aim of the work was to study the annual dynamics and seasonal changes of organic (determined by the content of $\mathrm{C}_{\text {org. }}$ ) and mineral substances and nutrients in the atmospheric precipitation of Barnaul.

\section{Material and methods}

Samples were taken after each event in open area of the roof of the IWEP SB RAS building from October
2013 to March 2020. Before analysis samples of solid atmospheric precipitation (snow) were thawed in plastic containers at room temperature.

The amount of organic carbon was estimated by the value of chemical oxygen consumption (COD) (Alekin, 1953).

Major ions $\mathrm{NO}_{3}, \mathrm{Cl}, \mathrm{SO}_{4}^{2-}, \mathrm{Na}^{+}, \mathrm{K}^{+}, \mathrm{Mg}^{2+}, \mathrm{NH}_{4}^{+}$, $\mathrm{Ca}^{2+}$ ) were determined by ion chromatography on the ICS-3000 instrument (Dionex, USA), as well as by the photometric method on a DR 2800 spectrophotometer ( $\mathrm{HACH}$ Lange Company, Germany) ( $\left.\mathrm{NO}_{2}{ }^{-}, \mathrm{PO}_{4}{ }^{3-}\right)$. Samples of rain and snowmelt were filtered through a membrane filter with a pore diameter of $0.45 \mu \mathrm{m}$ in an atmosphere of inert gas (argon).

COD was determined in unfiltered samples on a DR-2800 spectrophotometer.

\section{Results and discussion}

For the study period (2013 - 2020) 720 samples of wet atmospheric precipitation of Barnaul were taken and analyzed.

Seasonal variability was observed for such indicators as $\mathrm{NO}_{3}, \mathrm{Cl}, \mathrm{SO}_{4}^{2-}, \mathrm{Na}^{+}, \mathrm{K}^{+}, \mathrm{PO}_{4}{ }^{3-}$. Their maximum concentrations were observed for the cold period of the year (October-March), which can be associated both with the use of these compounds as deicing products (Blaszczak et al., 2019) and the burning of coal during the heating season.

Concentrations of organic carbon and $\mathrm{NO}_{2}$, $\mathrm{Mg}^{2+}, \mathrm{NH}_{4}{ }^{+}, \mathrm{Ca}^{2+}$ ions had no seasonal changes during 
the year.

The annual content of the total amount of the studied ions, as well as $\mathrm{C}_{\text {org }}$, increased from year to year in proportion to the number of pollutants entering the atmosphere of Barnaul with industrial emissions and automobile exhaust (Report..., 2019).

\section{Conclusions}

The anthropogenic activity contributes to an annual increase in organic and mineral substances and nutrients in the atmosphere of Barnaul City.

The highest concentrations were observed in the cold season.

\section{Acknowledgments}

This study was carried out in the framework of the state task of the Institute for Water and Environmental Problems (AAAA-A17-117041210242-1) and project RFFR (Russian Found Fundamental Research) № 19-05-50057\19.
The authors are grateful to the staff of the Chemical-Analytical Center of the IWEP SB RAS for their assistance in sampling and analysis.

\section{References}

Alekin O.A. 1953. Osnovy gidrokhimii [Fundamentals of hydrochemistry]. Leningrad: Gidrometeoizdt. (in Russian)

Blaszczak J.R., Delesantro J.M., Zhong Y. et al. 2019. Watershed urban development controls on urban streamwater chemistry variability. Biogeochemistry 144: 61-84. DOI: 10.1007/s10533-019-00572-7

Golubnichy A.A., Lityuk T.S., Tyukalov P.A. 2014. The dynamics of air pollution in the city of Chernogorsk. Universum: Khimiya i Biologiya [Universum: Chemistry and Biology] 2: 1-8. (in Russian)

Report on the state and environmental protection of the urban district - the city of Barnaul, Altai Territory in 2018. 2019. Barnaul: OOO "Standart". https://barnaul.org/upload/ medialibrary/e0a/Doklad-2018.pdf (in Russian)

Svistov P.F., Polishchuk A.I. 2014. Precipitation over cities and regions of Russia. Priroda [Nature] 3: 28-36. (in Russian) 